\title{
Crystal Structure, Hirshfeld Surface Analysis and Computational Studies of Thiazolidin-4-one derivative: (Z)-5-(4-Chlorobenzylidene)-3-(2-ethoxyphenyl) -2-thioxothiazolidin-4-one
}

\author{
Nawel Khelloul, ${ }^{1}$ Khaled Toubal, ${ }^{2}$ Nadia Benhalima, ${ }^{1}$ Rachida Rahmani, ${ }^{1}$ \\ Abdelkader Chouaih, ${ }^{1, *}$ Ayada Djafri ${ }^{2}$ and Fodil Hamzaoui ${ }^{1}$ \\ ${ }^{1}$ Laboratory of Technology and Solid's Properties, Faculty of Sciences and Technology, \\ University Abdelhamid Ibn Badis of Mostaganem, 27000 Mostaganem, Algérie \\ ${ }^{2}$ Laboratoire de Synthèse Organique Appliquée (LSOA), Département de Chimie, Faculté des Sciences, \\ Université d'Oran 1 - Ahmed Ben Bella, 31000 Oran, Algérie \\ * Corresponding author: E-mail: achouaih@gmail.com
}

Received: 18-02-2016

\begin{abstract}
The title compound (Z)-5-(4-chlorobenzylidene)-3-(2-ethoxyphenyl)-2-thioxothiazolidin-4-one (CBBTZ) was characterized by X-ray single crystal diffraction, ${ }^{1} \mathrm{H}$ NMR and ${ }^{13} \mathrm{C}$ NMR spectra. Theoretical investigations were carried out using HF and DFT levels of theory at 6-31G(d,p) basis set. The X-ray structure is compared with that computed. The calculated geometrical parameters are in good agreement with those determined by X-ray diffraction. The dihedral angle between the two benzene rings is $16.89(5)^{\circ}$ indicating that the structure is non planar. The molecule exhibits intraand intermolecular contacts of type $\mathrm{C}-\mathrm{H} \cdots \mathrm{O}, \mathrm{C}-\mathrm{H} \cdots \mathrm{S}$ and $\mathrm{C}-\mathrm{H} \cdots \mathrm{Cl}$. The intercontacts in the crystal structure are explored using Hirshfeld surfaces analysis method.
\end{abstract}

Keywords: Structure, thiazolidin-4-one, theoretical calculations, intermolecular interactions, Hirshfeld surface

\section{Introduction}

Heterocyclic compounds containing five membered rings with nitrogen, sulfur, and oxygen atoms have been investigated since a long time for their important properties. Several theoretical and experimental investigations were performed to determine the absolute molecular con?guration of organic compounds containing fivemembered heterocyclic derivatives. ${ }^{1-3}$ Among these types of compounds, 4-thiazolidinones have been shown to have various significant activities. Furthermore, thiazolidinone derivatives have been developed into useful materials for a variety of applications, such as of biological interest, nonlinear optical field and photovoltaic cells. ${ }^{4-10}$ Organic photovoltaic compounds (OPVs) have attracted significant attention as low-cost alternatives to conventional semiconductor photovoltaic devices. ${ }^{1-13}$ Consequently, (Z)-5-(4-chlorobenzylidene) -3-(2-ethoxyp- henyl) -2-thioxothiazolidin-4-one (CBBTZ) is a interesting member of the above-mentioned molecules containing delocalized $\pi$ electrons with donor and acceptor groups. Appropriate electron donor and acceptor groups and $\pi$-conjugated system allow the CBBTZ to exhibit the asymmetric electronic distribution which leads to an increased charge transfer.

Recently, some studies have been carried out on CBBTZ. The optical, electrochemical and X-ray photoelectron spectroscopy (XPS) characterization of CBBTZ has been explored and CBBTZ thin films with electronic properties were also studied as an exciton blocking layer in $\mathrm{CuPc} / \mathrm{C} 60$ heterojunction solar cells. ${ }^{14,15}$

In this context, and in continuation of our works on thiazolidinones molecules, this study was aimed to report the structural properties and intermolecular interactions of CBBTZ.,16 


\section{Experiment and Computational Methods}

\section{1. Experimental}

Synthesis, Spectral Data and Spectral Analysis of (Z)-5-(4-Chlorobenzylidene)-3-(2-ethoxyphenyl)-2-thioxothiazolidin-4-one (CBBTZ)

Synthesis and spectral data (IR, ${ }^{1} \mathrm{H}$ NMR, ${ }^{13} \mathrm{C}$ NMR) of CBBTZ are reported in previous work. ${ }^{16}$ The structure of CBBTZ is presented in Scheme 1.

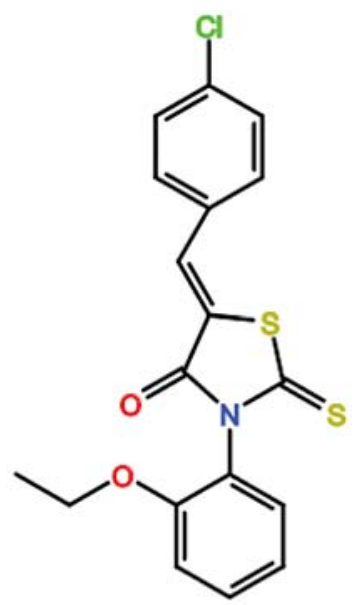

Scheme 1. (Z)-5-(4-Chlorobenzylidene)-3-(2-ethoxyphenyl)-2thioxothiazolidin-4-one (CBBTZ)

\section{2. X-Ray Structure Determination}

$\mathrm{X}$-Ray diffraction study was done on single crystal diffractometer Kappa CCD Nonius. X-Ray data have been measured using graphite monochromated MoK $\alpha$ radiation $(\lambda=0.71073 \AA)$ at ambient temperature. The program SHELXS-97 was used to solve the structure by direct methods. ${ }^{17}$ Then, full-matrix least-squares refinement using SHELXL-97 revealed the final structure. ${ }^{18}$ Hydrogen atoms were located in their calculated positions. Figure 1 shows the structure of CBBTZ along with the atomic labeling using ORTEP visualization program. ${ }^{19}$ For highlighting intra- and intermolecular interactions, Hirshfeld Surface analyses were performed and fingerprint plots were drawn using Crystal Explorer. ${ }^{20}$ Crystallographic details and refinement data are summarized in Table 1.

\section{3. Theoretical Approach}

Throughout this study, Gaussian 03 software $^{21}$ and Gauss-View program ${ }^{22}$ have been used to perform molecular modelling. B3LYP ${ }^{23,24}$ and $\mathrm{HF}^{25}$ methods were used to optimize the molecular structure of the title compound in the ground state using the $6-31 \mathrm{G}(\mathrm{d}, \mathrm{p})$ basis
Table 1. Crystallographic details and refinement data

\begin{tabular}{ll}
\hline Empirical formula & $\mathrm{C}_{18} \mathrm{H}_{14} \mathrm{ClNO}_{2} \mathrm{~S}_{2}$ \\
CCDC reference no. & 1044524 \\
Molecular weight & 375.87 \\
Crystal size (mm) & $0.19 \times 0.14 \times 0.11$ \\
Temperature $(\mathrm{K})$ & $295(2)$ \\
Crystal system, space group & Triclinic, $P \overline{1}$ \\
Unit cell dimensions & \\
$a(\AA)$ & $9.2171(19)$ \\
$b(\AA)$ & $8.4612(7)$ \\
$c(\AA)$ & $11.935(3)$ \\
$\alpha\left(^{\circ}\right)$ & $101.623(11)$ \\
$\beta\left(^{\circ}\right)$ & $90.89(2)$ \\
$\gamma\left({ }^{\circ}\right)$ & $118.148(9)$ \\
Wavelength $(\AA)$ & 0.71073 \\
Volume $\left(\AA^{3}\right)$ & $797.3(3)$ \\
$Z$, calculated density $\left(\mathrm{mg} / \mathrm{m}^{3}\right)$ & $2 / 1.566$ \\
$F(000)$ & 388 \\
Reflections collected/unique & $4080 / 2591$ \\
Parameters & 219 \\
Goodness of fit on $\mathrm{F}^{2}$ & 0.945 \\
Final R indices & \\
$R_{1}$ & 0.0562 \\
$w R_{2}$ & 0.1331 \\
$R$ indices (all data) & \\
$R_{1}$ & 0.0997 \\
$w R_{2}$ & 0.1683 \\
\hline
\end{tabular}

set. ${ }^{26,27}$ The spatial coordinate positions of the title compound, as obtained from X-ray structural investigation, were used as initial coordinates for the theoretical calculations.

\section{Results and Discussion}

\section{1. Description of the Crystal Structure}

Selected experimental geometrical parameters are summarized in Tables 2, 3 and 4. The molecular structure with atomic labelling (thermal ellipsoids are drawn at $50 \%$ probability) is depicted in Fig. 1. The thioxothiazol ring is essentially planar. The full molecule has a $Z$ configuration about the $C 7=C 8$ double bond (Figure 1). This $Z$ configuration of CBBTZ crystal is stabilized by intramolecular hydrogen bonds $\mathrm{C}-\mathrm{H} \cdots \mathrm{O}$ and $\mathrm{C}-\mathrm{H} \cdots \mathrm{S}$. The $\mathrm{CC}$ bond lengths in the phenyl rings have average value of $1.38 \AA$ obtained by X-ray diffraction and calculated mean values of $1.40 \AA$ and $1.39 \AA$ obtained with B3LYP and HF, respectively. The double bond of $\mathrm{C} 7=\mathrm{C} 8$ is characterized by the experimental distance of 1.332(8) $\AA$. The thiazole ring contains two $\mathrm{C}-\mathrm{S}$ bonds, namely

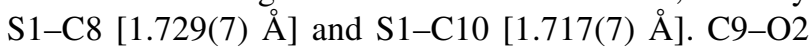
distance shows a typical double bond character with bond length of 1.198(7) $\AA$. The bond lengths are consistent with previous phenyl ring-containing studies. ${ }^{1}$ In the thiazole moiety formed by $\mathrm{C} 8, \mathrm{C} 9, \mathrm{C} 10, \mathrm{~N} 1$ and $\mathrm{S} 1$ 


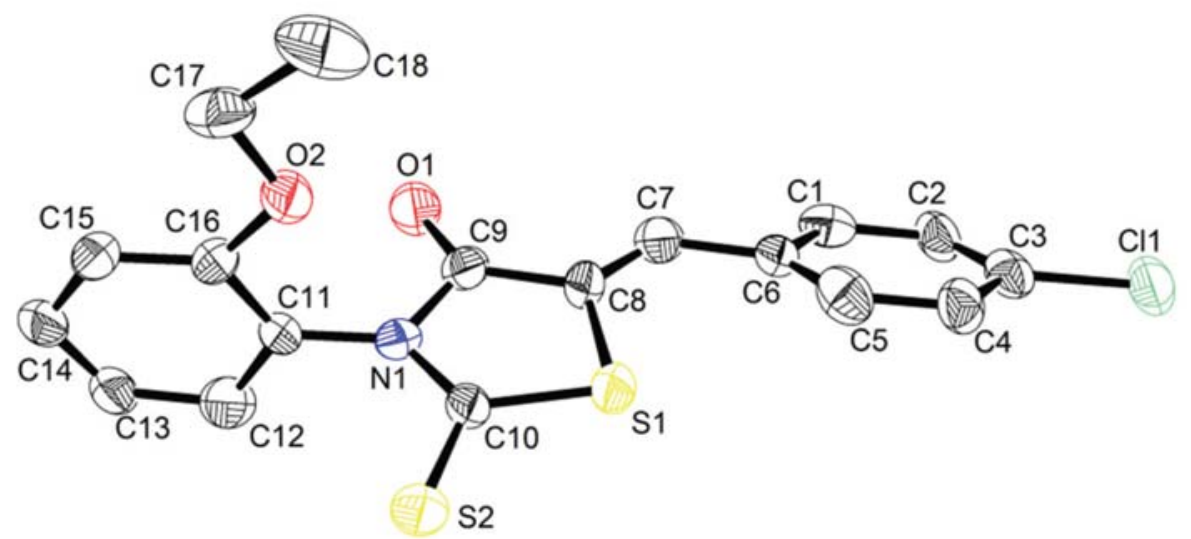

Figure 1. Structure of CBBTZ with atomic labeling scheme (ellipsoids are drawn at 50\% probability). For clarity, the hydrogen atoms are omitted.

atoms, the average value of bond angles is $108(5)^{\circ}$. In addition, delocalization of the $\pi$ electrons in CBBTZ is confirmed by $\mathrm{C}-\mathrm{C}-\mathrm{C}, \mathrm{C}-\mathrm{N}-\mathrm{C}$ and $\mathrm{C}-\mathrm{C}-\mathrm{N}$ bond angles which are around $120^{\circ}$. The torsion angle between the two benzene $(\mathrm{C} 1-\mathrm{C} 6)$ and $(\mathrm{C} 11-\mathrm{C} 16)$ rings is $16.89(5)^{\circ}$. The ethoxyphenyl group is twisted slightly, with a C9-N1-C11-C12 torsion angle of 82.9(12) ${ }^{\circ}$. The two moieties chlorobenzene and thioxothiazolidinone are nearly planar according to the dihedral angle C5-C6-C7-C8 of $16.4(18)^{\circ}$ (X-ray diffraction) and from $172.5^{\circ}$ to $179.5^{\circ}$ (theoretical calculation). As mentioned in our previous work, ${ }^{16}$ the chirality of this kind of compounds is highlighted by the value of the dihedral angle formed by the heterocyclic ring and the aryl bound at the nitrogen atom. In the present study, this angle is $95.8^{\circ}$. As we can easily see from the above results, there is a good correlation between the experimental and theoretical structural results. The observed differences are due to the fact that experimental results belong to the solid phase, while theoretical calculations belong to the

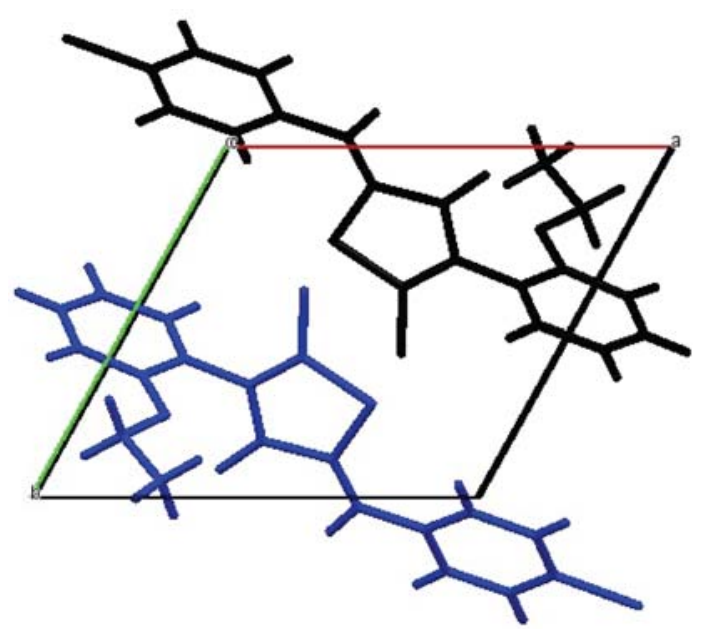

Figure 2. A perspective view of the crystal packing in the unit cell. View along the $c$ axis. gas phase of isolated molecules. The molecular packing in the crystal structure of CBBTZ is stabilized by intermolecular interactions forming a three-dimensional network (Figure 2).

\section{2. DFT and HF Optimized Geometry}

Figure 3 depicts the calculated molecular structure of CBBTZ using the B3LYP/6-31G(d,p) level of theory. Theoretical geometric parameters by HF and DFT levels of theory using $6-31 \mathrm{G}(\mathrm{d}, \mathrm{p})$ basis set are given in Tables 2,3 and 4 together with the experimental ones. The theoretical structural results of CBBTZ have a little different values compared with corresponding experimental results. Thus, bond length values of the thiazole ring $\mathrm{N} 1-\mathrm{C} 9$ and N1-C10 are 1.411 and $1.377 \AA$ computed with B3LYP, with respect to the X-ray results $1.379(8)$ and $1.330(7) \AA$, respectively. In the same context, calculated distances S1-C8 $(1.765 \AA)$ and S1-C10 (1.763 $\AA$ ) are comparable to the experimental values $(1.729(7)$ and $1.716(7) \AA)$. The $\mathrm{C}-\mathrm{C}$ distances in the two aromatic cycles vary from 1.380 (8) to 1.401(8) $\AA$ compared to the theoretical values which vary from 1.389 to $1.415 \AA$. According to the above results, deviations of $0.01 \AA$ for bond lengths and $3^{\circ}$ for bond and torsion angles are found between experimental

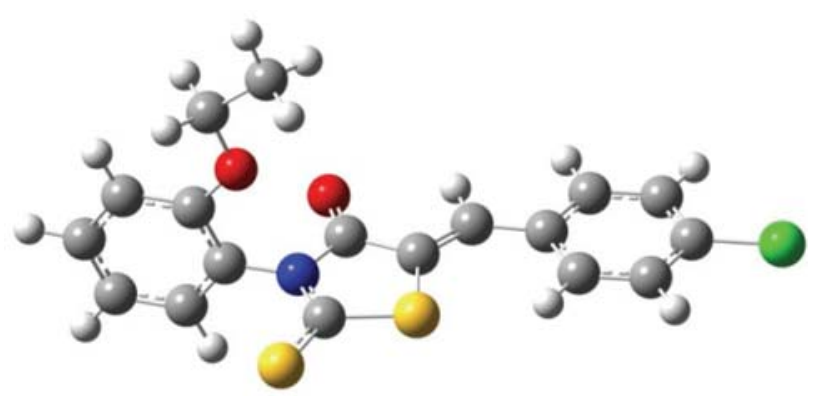

Figure 3. Theoretical crystal structure of CBBTZ with B3LYP/6$31 \mathrm{G}(\mathrm{d}, \mathrm{p})$ level. 
and theoretical geometries. This can be explained by considering that the theoretical calculations were carried out in a gaseous phase, whereas the X-ray diffraction study was performed on the compound in the solid form. Figure 4 compares the calculated structure to that obtained by $\mathrm{X}$-ray diffraction.

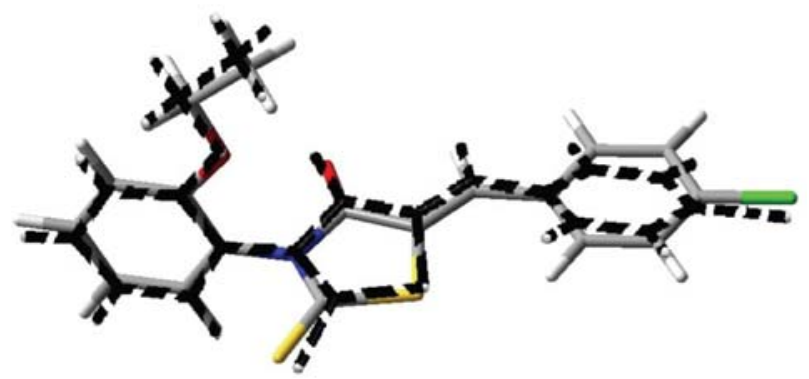

Figure 4. Atom-by-atom superimposition of the structures calculated (solid line) over the X-ray structure (dashed line) for CBBTZ.

Table 2. Experimental and calculated bond lengths

\begin{tabular}{llcr}
\hline $\begin{array}{l}\text { Bond distances } \\
\text { (̊) }\end{array}$ & \multirow{2}{*}{ X-ray } & \multicolumn{2}{c}{ 6-31G(d,p) } \\
\hline S1C8 & $1.729(7)$ & 1.775 & DFT \\
S1C10 & $1.716(7)$ & 1.745 & 1.763 \\
S2C10 & $1.600(7)$ & 1.634 & 1.642 \\
O1C9 & $1.198(7)$ & 1.209 & 1.213 \\
O2C16 & $1.356(7)$ & 1.340 & 1.357 \\
O2C17 & $1.404(12)$ & 1.411 & 1.431 \\
N1C9 & $1.379(8)$ & 1.395 & 1.411 \\
N1C10 & $1.330(7)$ & 1.354 & 1.377 \\
N1C11 & $1.403(7)$ & 1.432 & 1.436 \\
C7C8 & $1.332(8)$ & 1.336 & 1.352 \\
C8C9 & $1.467(8)$ & 1.486 & 1.482 \\
\hline
\end{tabular}

Table 3. Experimental and calculated bond angles

\begin{tabular}{lrrr}
\hline $\begin{array}{l}\text { Bond angles } \\
\text { (̊) }\end{array}$ & X-ray & \multicolumn{2}{c}{ 6-31G(d,p) } \\
\hline S1C10N1 & $123.0(5)$ & 110.19 & 109.31 \\
S1C8C7 & $124.0(6)$ & 120.31 & 119.60 \\
S1C8C9 & $111.3(5)$ & 108.47 & 109.81 \\
S2C10N1 & $120.8(5)$ & 127.33 & 127.30 \\
S2C10S1 & $116.2(4)$ & 122.46 & 123.38 \\
O1C9N1 & $113.3(7)$ & 122.19 & 121.87 \\
O1C9C8 & $132.4(8)$ & 127.54 & 127.91 \\
N1C9C8 & $114.2(6)$ & 110.25 & 110.21 \\
C8S1C10 & $85.6(3)$ & 93.10 & 93.40 \\
C9N1C10 & $105.7(6)$ & 117.93 & 118.08 \\
C9N1C11 & $123.8(6)$ & 119.45 & 119.73 \\
C10N1C11 & $130.4(7)$ & 122.29 & 122.04 \\
C7C8C9 & $124.1(7)$ & 120.20 & 119.47 \\
\hline
\end{tabular}

Table 4. Experimental and calculated dihedral angles

\begin{tabular}{lcrr}
\hline Torsion angles & \multirow{2}{*}{ X-ray } & \multicolumn{2}{c}{$\mathbf{6 - 3 1 G ( d , p )}$} \\
(A) & & 178.9 & DFT \\
\hline S1C8C9O1 & $179.8(10)$ & -1.8 & -0.9 \\
S1C8C9N1 & $-3.1(10)$ & -1.9 & -0.2 \\
S1C8C7C6 & $-9.2(15)$ & -2.2 & -1.6 \\
S1C10N1C9 & $3.5(10)$ & -175.6 & -177.1 \\
S1C10N1C11 & $-172.4(7)$ & -179.6 & -179.5 \\
S2C10S1C8 & $177.1(6)$ & 178.2 & 178.8 \\
S2C10N1C9 & $-178.3(7)$ & 4.8 & 3.2 \\
S2C10N1C11 & $5.8(13)$ & -178.1 & -178.8 \\
O1C9N1C10 & $177.6(9)$ & -4.4 & -3.2 \\
O1C9N1C11 & $-6.1(13)$ & -2.4 & -0.7 \\
O1C9C8C7 & $-8.8(18)$ & 176.7 & 178.7 \\
N1C9C8C7 & $168.3(9)$ & 3.1 & 1.8 \\
N1C10S1C8 & $-4.6(8)$ & 1.5 & 0.2 \\
C6C7C8C9 & $-179.5(9)$ & -178.1 & -179.6 \\
C10S1C8C7 & $-167.5(9)$ & 0.6 & 0.1 \\
C10S1C8C9 & $3.8(7)$ & 2.6 & 1.7 \\
C10N1C9C8 & $-0.1(11)$ & 176.3 & 177.3 \\
C11N1C9C8 & $176.2(7)$ & -84.7 & -86.9 \\
C9N1C11C12 & $-82.9(12)$ & 88.6 & 88.5 \\
C10N1C11C12 & $92.4(12)$ & 94.4 & 95.4 \\
C9N1C11C16 & $96.5(11)$ & -90.2 & -89.6 \\
C10N1C11C16 & $-88.2(12)$ & & \\
\hline & & &
\end{tabular}

\section{3. Intermolecular H-Bonds}

$\mathrm{C}-\mathrm{H} \cdots \mathrm{O}, \mathrm{C}-\mathrm{H} \cdots \mathrm{S}$ and $\mathrm{C}-\mathrm{H} \cdots \mathrm{Cl}$ intra- and intermolecular interactions are present in the crystal structure. These interactions are responsible for the stability of the crystal structure. C atoms, namely C2, C4, C5, C7, C14 and $\mathrm{C} 18$ act as donors and $\mathrm{O}$ atoms, namely $\mathrm{C} 2, \mathrm{C} 4, \mathrm{C} 5$, C7, C14 and C18 act as acceptors. H-Bond interactions are presented in Table 5. Figure 5 shows $\mathrm{C} 7 \mathrm{H} 7 \cdots \mathrm{O} 1 \mathrm{H}-$ bond in the crystal.

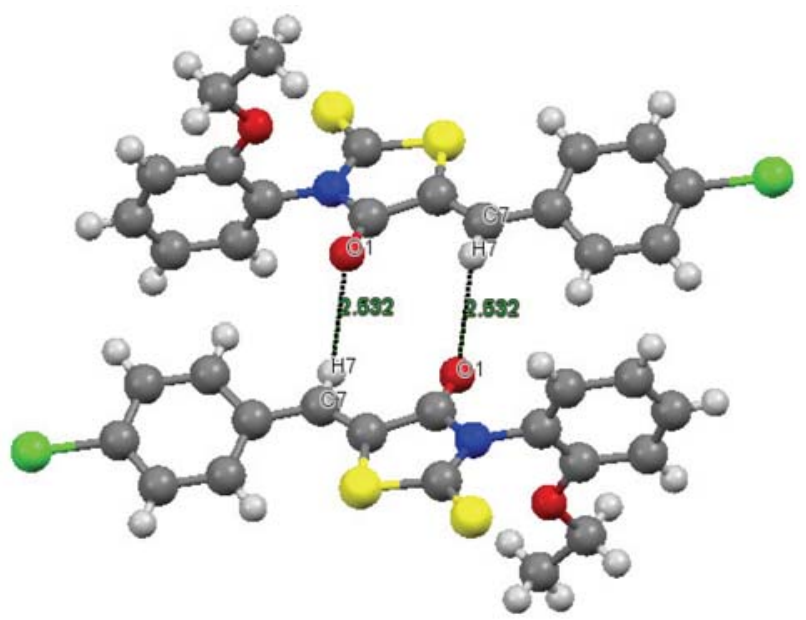

Figure 5. C-H $\cdots \mathrm{O}, \mathrm{C}-\mathrm{H} \cdots \mathrm{S}$ and $\mathrm{C}-\mathrm{H} \cdots \mathrm{Cl} \mathrm{H}-$ bond in the crystal. 
Table 5. C-H $\cdots \mathrm{O}, \mathrm{C}-\mathrm{H} \cdots \mathrm{S}$ and $\mathrm{C}-\mathrm{H} \cdots \mathrm{Cl}$ H-bonds in $\mathrm{CBBTZ}$ crystal.

\begin{tabular}{|c|c|c|c|c|}
\hline$\overline{\mathbf{D H} \cdots \mathbf{A}}$ & DH & $\mathbf{H} \cdots \mathbf{A}$ & $\mathbf{D} \cdots \mathbf{A}$ & DH $\cdots A$ \\
\hline$\overline{\mathrm{C} 5 \mathrm{H} 5 \cdots \mathrm{S} 1}$ & 0.93 & 2.48 & $3.082(8)$ & 122.5 \\
\hline $\mathrm{C} 2 \mathrm{H} 2 \cdots \mathrm{S} 1^{\mathrm{i}}$ & 0.93 & 2.96 & 3.647 (11) & 131.9 \\
\hline $\mathrm{C} 2 \mathrm{H} 2 \cdots \mathrm{Cl} 1^{\mathrm{ii}}$ & 0.93 & 2.83 & $3.313(11)$ & 113.1 \\
\hline $\mathrm{C} 4 \mathrm{H} 4 \cdots \mathrm{O} 2^{\mathrm{iii}}$ & 0.93 & 2.77 & $3.575(13)$ & 145.3 \\
\hline $\mathrm{C} 7 \mathrm{H} 7 \cdots \mathrm{O} 1^{\text {iv }}$ & 0.93 & 2.53 & $3.110(13)$ & 134.5 \\
\hline $\mathrm{C} 14 \mathrm{H} 14 \cdots \mathrm{S} 1^{\mathrm{v}}$ & 0.93 & 2.98 & $3.354(14)$ & 105.4 \\
\hline $\mathrm{C} 18 \mathrm{H} 18 \mathrm{~B} \cdots \mathrm{S} 1^{\mathrm{vi}}$ & 0.96 & 2.92 & 3.747 (13) & 144.7 \\
\hline
\end{tabular}

Symmetry codes:

(i) $-x+1,-y,-z$; (ii) $-x,-y-1,-z$; (iii) $x-1,+y,+z$;

(iv) $-x+2,-y,-z$; (v) $x+1,+y,+z$; (vi) $-x+2,-y,-z+1$.

\section{4. Hirshfeld Surface Analysis}

Hirshfeld surface (HS) analysis represents a unique approach towards an understanding of different interactions in the crystal structure and is a necessary tool in crystal engineering. In addition to the HS analysis, the fingerprint plots also provide some useful quantitative information about the individual contribution of each intermolecular interaction in the crystal packing. The intra- and intermolecular interactions of CBBTZ crystal are quantified using HS analysis. The three-dimensional HS generated for structure of CBBTZ crystal is presented in Fig. 6. The red contacts highlight the intermolecular interactions with distances closer than the sum of the van der Waals radii, while white indicates contacts near the van der Waals separation, and blue depicts longer contacts. ${ }^{28}$ Figure 7 shows Hirshfeld surfaces mapped for CBBTZ compound with the shape index property (a) and with $d_{\text {norm }}$ selected intermolecular contacts (b). The full fingerprint plot for the CBBTZ crystal and the contribution of each type of interaction to the total HS are presented in Figure 8 displaying surfaces that were mapped over $d_{\text {norm }}(0.242$ to 1.414$)$.

As seen in Figure 7, the deep red colour indicates hydrogen-bonding contacts. For example, a deep red spot indicated the presence of a $\mathrm{CH} \cdots \mathrm{O}$ H-bond (between $\mathrm{H} 7$ and $\mathrm{O} 1$ ). The other colour spots are observed due to the presence of other close contacts, such as $\mathrm{H} \cdots \mathrm{H}, \mathrm{C} \cdots \mathrm{H}$, $\mathrm{S} \cdots \mathrm{H}, \mathrm{O} \cdots \mathrm{H}$ and $\mathrm{Cl} \cdots \mathrm{H}$. The fingerprint plots of CBBTZ are dominated by $\mathrm{H} \cdots \mathrm{H}$ and $\mathrm{C} \cdots \mathrm{H}$ contacts. The remaining area of the fingerprint plot is occupied by C... $(3.2 \%)$, $\mathrm{Cl} \cdots \mathrm{C}(2.9 \%), \mathrm{Cl} \cdots \mathrm{O}(2 \%), \mathrm{S} \cdots \mathrm{S}(1.5 \%), \mathrm{C} \cdots \mathrm{S}(0.9 \%)$, $\mathrm{Cl} \cdots \mathrm{Cl}(0.8 \%), \mathrm{C} \cdots \mathrm{O}(0.6 \%), \mathrm{Cl} \cdots \mathrm{N}(0.2 \%), \mathrm{Cl} \cdots \mathrm{S}(0.1 \%)$ and $\mathrm{O} \cdots \mathrm{O}(0.1 \%)$ contact regions. The molecular stacking, in spite of having a considerable energetic stabilization, contributes much less [C … C (3.2\%)] towards the crystal packing. The $\mathrm{H} \cdots \mathrm{H}$ contacts, which are prominent in the molecular packing, appear as the scattered points along with double broad peaks in the middle of the region of the fingerprint plot. The positions of the peaks marked with (2) in Fig. 8(a), are at $d_{e}=d_{i}=1.2$ and $1.0 \AA$, and the percent contribution is $28.4 \%$. The contribution from $\mathrm{C} \cdots \mathrm{H}$
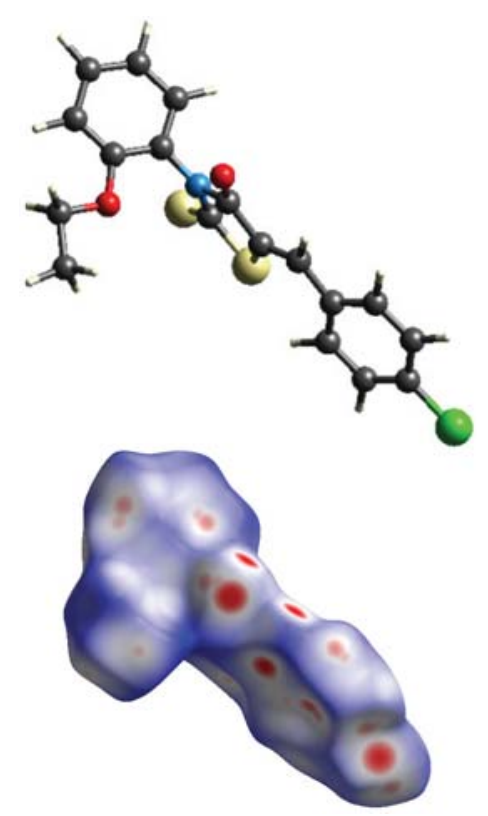

Figure 6. View of the HS for CBBTZ molecule.

a)

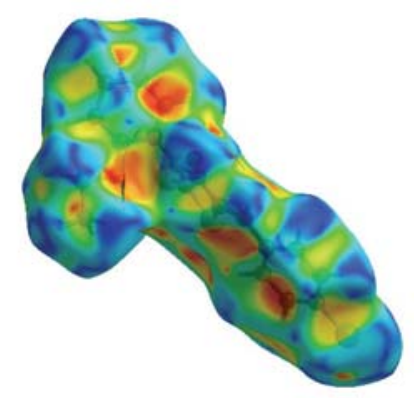

b)

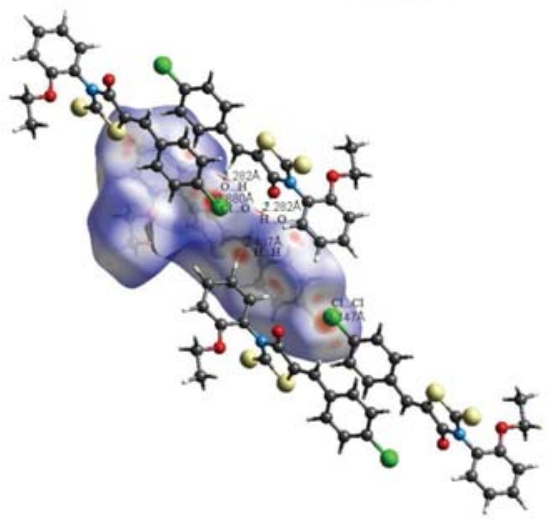

Figure 7. HS mapped for CBBTZ compound with (a) the shape index property $(b) d_{\text {norm }}$ selected intermolecular contacts.

contacts $(24.4 \%$ of the HS) results in a symmetrical pair of wings, see Fig. 8(c). The prominent spikes at $d_{e}=d_{i}=$ $1.8 \AA$ are due to $\mathrm{S} \cdots \mathrm{H}$ contacts. These contributions are highlighted in the fingerprint plot, Fig. 8(d). For the title compound, $\mathrm{H} \cdots \mathrm{O}$ contacts, which are attributed to $\mathrm{CH} \cdots \mathrm{O}$ H-bond interactions, occur as two sharp symmetric spikes in the two dimensional fingerprint map. The presence of 
these long spikes (indicated by (1) in Fig. 8) is characteristic of strong hydrogen bonds. The intermolecular $\mathrm{O} \cdots \mathrm{H}$ and $\mathrm{H} \cdots \mathrm{O}$ contacts, Fig. 8( $a$ and $e)$ and Fig. 9, provide contribution of $8.3 \%$ to the HS of the CBBTZ crystal. Figure $8(f)$ shows the contribution of $\mathrm{Cl} \cdots \mathrm{H}$ intermolecular contacts to the HS.

The quantitative results of the HS analysis for the CBBTZ crystal are presented in Fig. 9 which gives a de- tailed quantitative analysis of all intra- and intermolecular contacts contributing to the HS.

\section{Conclusion}

A novel thiazolidinone derivate, (Z)-5-(4-chlorobenzylidene)-3-(2-ethoxyphenyl)-2-thioxothiazolidin-4-
Full (100\%)

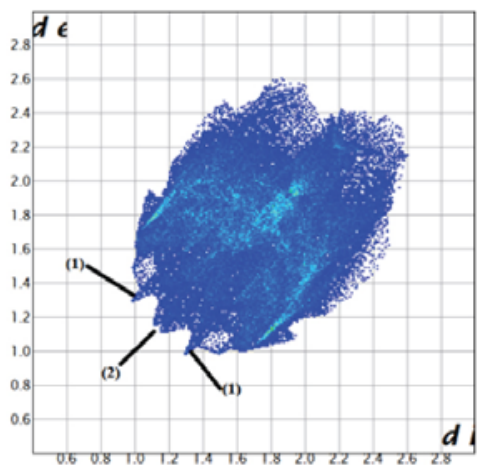

a)

$\mathrm{S} \cdots \mathrm{H}(18.6 \%)$

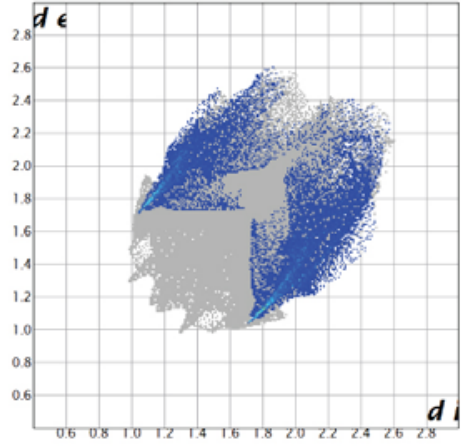

d)
$\mathrm{H} \cdots \mathrm{H}(28.4 \%)$

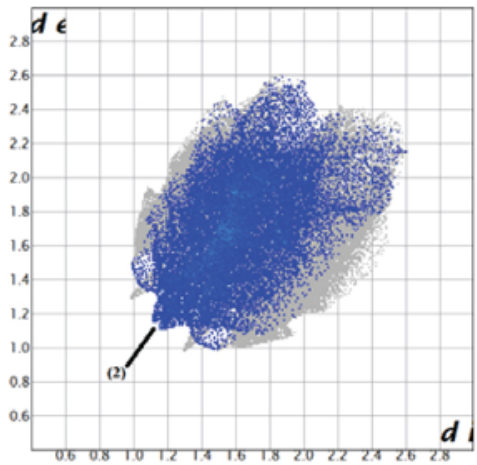

b)

$$
\mathrm{O} \cdots \mathrm{H} / \mathrm{H} \cdots \mathrm{O}(8.3 \%)
$$

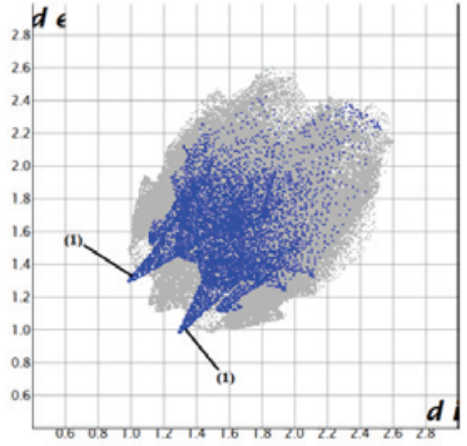

e)
$\mathrm{C} \cdots \mathrm{H}(24.4 \%)$

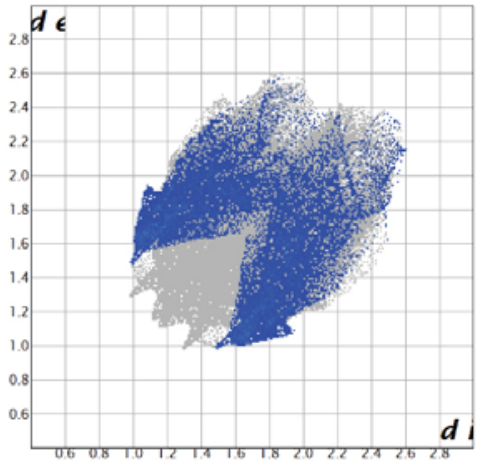

c)

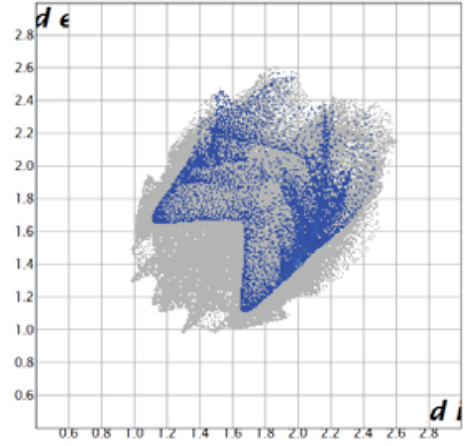

f)

Figure 8. The 2D fingerprint plots showing the percentage contribution of the individual types of interaction to the total HS area.

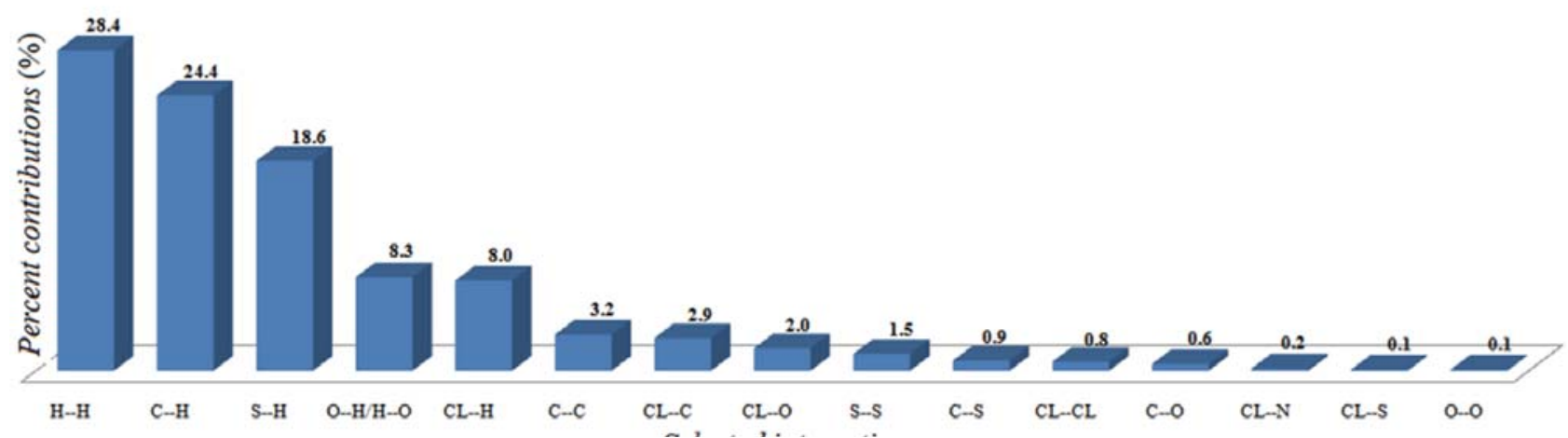

Figure 9. Quantitative results of different intra- and intermolecular interactions contributing to the HS. 
one (CBBTZ) has been investigated for the first time. Its structural properties have been examined by theoretical calculations using HF and DFT methods and X-ray diffraction technique. CBBTZ crystallizes in the triclinic system with the space group P-1. Obtained results indicate that the theoretical calculations can reproduce the experimental results. In the crystal packing, the molecules are connected by intra- and intermolecular $\mathrm{H}$-bonds of the type $\mathrm{C}-\mathrm{H} \cdots \mathrm{O}$, $\mathrm{C}-\mathrm{H} \cdots \mathrm{S}$ and $\mathrm{C}-\mathrm{H} \cdots \mathrm{Cl}$. In general, a good agreement was observed between the calculated geometrical parameters (with B3LYP) and that of reported similar derivatives. All the calculated data and experimental results of the studied molecule are useful in the application in fundamental research in chemistry and photovoltaic cells in the future. Finally, HS analysis and fingerprint plots are a unique way for understanding the contribution of individual types of interactions within the crystal structure. More theoretical calculations can be performed on this compound to assess other properties especially in the photovoltaic field.

\section{Supplementary Material}

Crystallographic data for the structure reported in this article have been deposited with Cambridge Crystallographic Data Center, CCDC 1044524. Copies of this information may be obtained free of charge from the Director, CCDC, 12 Union Road, Cambridge, CBZ IEZ, UK. Facsimile (44) 01223336 033, E-mail: deposit@ ccdc. cam.ac.uk or http//www.ccdc.com.ac.uk/deposit.

\section{References}

1. N. Benhalima, K. Toubal, A. Chouaih, G. Chita, S. Maggi, A. Djafri, F. Hamzaoui, J. Chem. Crystallogr. 2011, 41, 1729-1736. http://dx.doi.org/10.1007/s10870-011-0165-9

2. N. Özdemir, M. Dinçer, A. Çukurovalý, J. Mol. Model. 2010, 16, 291-302. http://dx.doi.org/10.1007/s00894-009-0552-8

3. R. Anbazhagan, K. R. Sankaran, J. Mol. Struct. 2013, 1050, 73-80. http://dx.doi.org/10.1016/j.molstruc.2013.07.019

4. N.K. Fuloria, V. Singh, M.S. Yar, M. Ali, Acta Pol. Pharm. Drug Res. 2009, 66, 141-147.

5. C. Nandagokula, B. Poojary, S. Vittal, S. Shenoy, P. Shetty, A. Tangavelu, Med Chem Res. 2013, 22(1), 253-266. http://dx.doi.org/10.1007/s00044-012-0028-8

6. R. V. Patel, S. W. Park, Res. Chem. Intermed. 2015, 41, 5599-5609. http://dx.doi.org/10.1007/s11164-014-1684-8

7. P. Chawla, R. Singh, S. K. Saraf, Med Chem Res. 2012, 21, 2064-2071. http://dx.doi.org/10.1007/s00044-011-9730-1

8. V. Smokal, B. Derkowska, R. Czaplicki, O. Krupka, A. Kolendo, B. Sahraoui, Opt. Mater. 2009, 31, 554-557. http://dx.doi.org/10.1016/j.optmat.2007.10.019

9. M. M. Oliva, J. Casado, M. M. M. Raposo, A. M. C. Fonseca, H. Hartmann, V. Hernández, et al., J. Org. Chem. 2006, 71, 7509-7520. http://dx.doi.org/10.1021/jo060318v

10. L. Duan, J. Qiao, Y.D. Sun, Y. Qiu, Adv. Mater. 2011, 23(9), 1137-1144. http://dx.doi.org/10.1002/adma.201003816

11. P. V. Kamat, M. Haria, S. Hotchandani, J. Phys. Chem. B, 2004, 108, 5166-5170. http://dx.doi.org/10.1021/jp0496699

12. C. Brabec, S. Gowrisanker, J. M. M. Halls, D. Laird, S. J. Jia, S. P. Williams, Adv. Mater. 2010, 22, 3839-3856. http://dx.doi.org/10.1002/adma.200903697

13. A. Lakhdar Toumi, A. Khelil, J. C. Bernède, Y. Mouchaal, A. Djafri, K. Toubal, N. Hellal, L. Cattin, Surface Review and Letters 2015, 22(2), 1550025-1550033.

http://dx.doi.org/10.1142/S0218625X15500250

14. A.S. Yapi, L. Toumi, Y. Lare, G.M. Soto, L. Cattin, K. Toubal, A. Djafri, M. Morsli, A. Khelil, M.A. Del Valle, et al., Eur. Phys. J. Appl. Phys. 2010, 50, 30403-30411. http://dx.doi.org/10.1051/epjap/2010062

15. Y. Mouchaal, A. Lakhdar Toumi, A. S. Yapi , Y. Lare, G. M. Soto, L. Cattin , K. Toubal, A. Reguig, A. Khelil, A. Djafri, M. Morsli, M. A. Del Valle, J. C. Bernède, EPJ Web of Conferences 2012, 29, 00030-00036.

http://dx.doi.org/10.1051/epjconf/20122900030

16. K. Toubal, A. Djafri, A. Chouaih, A. Talbi, Molecules 2012, 17, 3501-3509. http://dx.doi.org/10.3390/molecules 17033501

17. G. M. Sheldrick, SHELXS97 Program for crystal structure determination, University of Göttingen, Göttingen, Germany, 1997.

18. G. M. Sheldrick, SHELXL97 Program for crystal structure refinement, University of Göttingen, Göttingen, Germany, 1997.

19. L. J. Farrugia, J. Appl. Crystallogr. 1997, 30, 565-565. http://dx.doi.org/10.1107/S0021889897003117

20. S. K. Wolff, D. J. Grimwood, J. J. Mckinnon, D. Jayatilaka, M. A. Spackmann, "Crystal Explorer 3.0”, University of Western Australia, Perth, Western Australia, 2007.

21. M. J. Frisch, G. W. Trucks, H. B. Schlegel, G. E. Scuseria, M. A. Robb, J. R. Cheeseman, J. A. Montgomery, Jr., T. Vreven, K. N. Kudin, J. C. Burant, J. M. Millam, S. S. Iyengar, J. Tomasi, V. Barone, B. Mennucci, M. Cossi, G. Scalmani, N. Rega, G. A. Petersson, H. Nakatsuji, M. Hada, M. Ehara, K. Toyota, R. Fukuda, J. Hasegawa, M. Ishida, T. Nakajima, Y. Honda, O. Kitao, H. Nakai, M. Klene, X. Li, J. E. Knox, H. P. Hratchian, J. B. Cross, V. Bakken, C. Adamo, J. Jaramillo, R. Gomperts, R. E. Stratmann, O. Yazyev, A. J. Austin, R. Cammi, C. Pomelli, J. W. Ochterski, P. Y. Ayala, K. Morokuma, G. A. Voth, P. Salvador, J. J. Dannenberg, V. G. Zakrzewski, S. Dapprich, A. D. Daniels, M. C. Strain, O. Farkas, D. K. Malick, A. D. Rabuck, K. Raghavachari, J. B. Foresman, J. V. Ortiz, Q. Cui, A. G. Baboul, S. Clifford, J. Cioslowski, B. B. Stefanov, G. Liu, A. Liashenko, P. Piskorz, I. Komaromi, R. L. Martin, D. J. Fox, T. Keith, M. A. Al-Laham, C. Y. Peng, A. Nanayakkara, M. Challacombe, P. M. W. Gill, B. Johnson, W. Chen, M. W. Wong, C. Gonzalez, and J. A. Pople, Gaussian 03, Revision C.02, Gaussian, Inc., Wallingford CT, USA, 2004. 
22. A. E. Frisch, A. B. Nielsen, A. J. Holder, Gaussview, Gaussian Inc., Pittsburg, USA, 2003.

23. A. D. Becke, J. Chem. Phys., 1997, 107, 8554-8560. http://dx.doi.org/10.1063/1.475007

24. G. Rauhut, P. Pulay, J. Phys. Chem. 1995, 99, 3093-3100. http://dx.doi.org/10.1021/j100010a019

25. H. D. Cohen, C. C. Roothaan, J. Chem. Phys. 1965, 43, S34. http://dx.doi.org/10.1063/1.1701512

26. R. Fletcher, M. J. D. Powell, Comput. J. 1963, 6, 163-168.

27. R. F. Bader, Atoms in Molecules. A Quantum Theory, Clarendon Press, Oxford, GB, 1990.

28. J. J. Mckinnon, D. Jayatilaka, M. A. Spackman, Chem. Commun. 2007, 37, 3814-3816.

http://dx.doi.org/10.1039/B704980C

\section{Povzetek}

Naslovno spojino (Z)-5-(4-klorobenziliden)-3-(2-etoksifenil)-2-tioksotiazolidin-4-on (CBBTZ) smo karakterizirali z rentgensko difrakcijo na monokristalu ter ${ }^{1} \mathrm{H}$ in ${ }^{13} \mathrm{C}$ NMR spektri. Teoretične izračune smo izvedli s pomočjo teorije na nivoju HF in DFT z uporabo 6-31G(d,p) baznega seta. Rentgensko strukturo smo primerjali z izračunano in ugotovili, da se izračunani geomterijski parametri dobro ujemajo $s$ tistimi, ki smo jih dobili z rentgensko difrakcijo. Dihedralni kot med dvema benzenovima obročema je $16.89(5)^{\circ}$, kar nakazuje, da struktura ni planarna. Molekula izkazuje tudi intra- in intermolekularne kontakte, npr. $\mathrm{C}-\mathrm{H} \cdots \mathrm{O}, \mathrm{C}-\mathrm{H} \cdots \mathrm{S}$ in $\mathrm{C}-\mathrm{H} \cdots \mathrm{Cl}$. Interakcije v kristalni strukturi smo raziskali s pomočjo metode Hirschfeldovih površin. 